\title{
The fight-to-die: older people and death activism
}

\author{
By NAOMI RICHARDS*
}

\begin{abstract}
This article explores the activities and convictions of older right-to-die activists who belong to a small but very active interest group based in Scotland, UK, called Friends at the End (FATE). The analysis presented here is based on knowledge gained through seventeen months of ethnographic research with the organisation. While FATE activists currently campaign for a legal right to a medically assisted death, many are also open to taking matters into their own hands, either by travelling to the Swiss organisation Dignitas or by opting for what is known as "self-deliverance". FATE members' openness to different means of securing a hastened death contrasts sharply with the more limited demands of the UK's main right-to-die organisation, Dignity in Dying, and highlights their specific orientation to freedom, which, it is argued here, results from the organisation's older demographic.
\end{abstract}

Keywords: right-to-die, euthanasia, activism, social movements, endof-life, autonomy.

* Naomi Richards, Department of Sociological Studies, University of Sheffield, Sheffield, UK 
International Journal of Ageing and Later Life

\section{Introduction}

In the public imagination, activism is often associated with youth. This assumption is perhaps based on an idea that older people have dwindling energy and less passion than younger people, both of which qualities are required to organise collectively. Barbara Macdonald (1985: 28), for example, in her collection of essays on ageism and older women, recounts an incident on a Reclaim the Night march, where one of the organisers singles her out for not "keeping up" with the other demonstrators. At sixty-five years of age she is seen as an anomaly in a demonstration consisting almost entirely of younger people. Although older people's continuing civic and productive engagement (e.g. Burr et al. 2002; Martinson \& Minkler 2006; Morrow-Howell 2000), volunteerism (e.g. Choi 2003; Warburton \& McLaughlin 2005) and participation in policy processes (Barnes 2005) have all been examined, research into the active involvement of older people in new social movements or direct action is lacking. Equally, the preponderance of older activists in the right-to-die movement in the UK also remains under-explored, within both the gerontological and the death studies literature. This could be due to the fact that it is only in the last decade that right-to-die activists have garnered the requisite media attention to make their collective voice heard, including, perhaps, by academics. The reasons for the increase in media coverage are multiple and various, and I will explore some of them in this article. Another possible reason for a seeming reluctance to explore the connection between older age and death activism might be linked to a more general aim to dissociate older people from death and dying. This has been attributed to a desire to break the "naturalised" link between death and old age and/or to prioritise positive images of ageing unencumbered by references to deterioration and death (Lloyd 2004: 243).

It is argued here, however, that there remains much to be gained from a sustained enquiry into the passion and conviction of this small but vociferous and relentless campaigning force. This article sets out to determine what is distinctive about the involvement of older people in a highly contentious debate in the hope that it will illuminate both the motivations of those involved and the broader ethical dimensions of the UK right-to-die movement. Participation in the right-to-die movement as a 
whole is not limited to an older demographic, nor are the parameters of the debate defined by its demographic. However, older activists are drawn to the cause not just as a result of personal identification, as Gilleard and Higgs argue (2000: 71), but also because of their social identity as older people. It is the intersection of old age and death activism that this article seeks to explore through an examination of the activities and convictions of a group of right-to-die activists, based in Scotland, called Friends at the End (FATE). I do not intend to focus on arguments for and against assisted dying, as this is a well-rehearsed debate. Instead, I describe older activists' perspectives in order to draw theoretical conclusions about the existence and form of their activism and its relationship to the wider debate about assisted dying.

First, I give a brief summary of FATE's origin and activities. I then briefly discuss why older people are likely to join FATE. One of the common motivations is fear of a "bad death" - for themselves and/or others - and so what constitutes a bad death, as activists envisage it, is important in order to grasp the nature of their activism. I will then go on to compare FATE's raison d'être with that of the UK's main national organisation, Dignity in Dying, which campaigns for a legal right to a medically hastened death. This comparison will highlight FATE members' specific orientation to freedom, which, I argue, owes something to the demographic of the organisation. The average age of FATE's members is 68 years, and $74 \%$ of the members are more than 60 (Judd \& Seale 2011). I suggest that the age of members gives their collective activism a sense of urgency in that they have started to think pragmatically about their mortality, and also an air of non-conformity in that they are less interested in maintaining corporate structures and hierarchical modes of governance, both factors setting them at odds with the more "professionalised" campaigners at Dignity in Dying. FATE members' frank discussions about the mechanics of dying and their descriptions of different bad death scenarios might sound morbid or obsessive to outsiders. Yet for FATE activists, acquiring knowledge about how to prepare for and plan for death helps to assuage their fears arising from the uncertainties surrounding the dying process. Their involvement in the right-to-die movement also gives members a sense of purpose and collective spirit as they fight to bring discussions about dying into the public arena. 
International Journal of Ageing and Later Life

\section{Methods}

This article is based on knowledge gained through involvement with the activities of FATE over the course of seventeen months. The fieldwork was carried out as part of a broader anthropological study of the UK rightto-die debate, the general aim of which was to discover whether or not this contentious and high-profile "conflict of rights" represents a new way of anticipating and talking about death. In research with FATE, the ethnographic method was employed in order to observe directly and participate in the activities of the group and collect descriptive data about their actions, beliefs and attitudes (Bryman 2001). While the ethnographic method is often criticised, largely on positivist grounds, for being impressionistic and lacking reliability, engaging with participants in their ordinary activities in naturally occurring settings over a long time period is the only way to contextualise the meanings that they attribute to their social world (Brewer 2000: 10). The ethnographic data collection undertaken with FATE involved: participation in the activities of the group, including attendance at five thrice-yearly meetings and other one-off events; accompanying activists to two international right-to-die conferences in consecutive years; multiple semi-structured interviews with five key members and multiple phone conversations and email exchanges with those key members; and sustained informal contact with approximately 15 other members and affiliates. Those FATE members who were interviewed in-depth were selected through purposive sampling in a desire to find information-rich cases (Patton 2001[1990]).

Contact with Dignity in Dying was more limited, involving: attendance at two Annual General Meetings; attendance at one-off events including a meeting of the All-Party Parliamentary Group "Compassion in Dying"; a formal interview with the Human Rights Officer; and informal contact at public debates and legal hearings with the Chief Executive, the Head of Legal Strategy and Policy, and the Director of Campaigns and Communications. The research was undertaken between October 2006 and February 2009. Although interviews were also undertaken with both high-profile and grassroots activists who strongly opposed any form of legalised assistance to die, requests to undertake the same type of sustained ethnographic inquiry of the main opposition organisation, Care Not Killing, were declined. I am therefore unable to make a comparison 
between FATE activists and Care Not Killing activists in terms of the influence of age on the form their activism takes. Care Not Killing was newly formed when first approached for access, and it is likely that some initial disorganisation may have contributed to its reluctance to grant me access. It should also be noted that at the time of conducting the research, those advocating for a change in the law (FATE and Dignity in Dying) were more "active" than those defending the status quo; hence, there were more activities to observe and participate in than would have been available through ethnographic interaction with Care Not Killing.

All data sources - extensive and detailed field notes about events, meetings and interviews; formal interview transcripts; supporting documentary evidence such as newsletters and campaign literature - were carefully read and re-read and then coded according to key themes (Scott Jones \& Watt 2010: 161) while the fieldwork was still ongoing. Identifying what was of significance to participants themselves was also part of this process. The ethnographic method has a distinctive openness (Katz 2001 [1983]: 202), which allowed me to direct the research purposively according to the need to flesh out the key themes arising. In the analysis stages, data from the different events, meetings and interviews were mined for their significance and then compared and contrasted in an iterative process. Data matrices were also created in order to cluster the evidence and draw connections between data (Scott Jones \& Watt 2010: 162-172). The evidence cited in this article is taken from all of the sources mentioned above and is also grounded in a detailed knowledge of the right-to-die debate in the UK. As is customary in ethnographic writing, I move between descriptive accounts of FATE and Dignity in Dying, and theoretical propositions.

Maintaining neutrality as a researcher is difficult in such a contentious bio-ethical debate. As a researcher, my utility for right-to-die participants rested with my (assumed) ability to offer them a platform upon which to air their views. However, it also entailed the hope or even the assumption that the research would endorse their particular perspective. In order to divest campaigners of this view I was very clear at the start of each interview that I wanted to access multiple perspectives; that I was examining the debate "in the round"; and that, above all, I held a neutral position on the central question of whether assisting someone to die is "right" or "wrong". As anthropologists who have studied human rights 
International Journal of Ageing and Later Life

activism have discovered, it can become problematic when researchers neglect or forsake their own ethical position in relation to the politics of the field in order to make their research more relevant to research participants (Jean-Klein \& Riles 2005). In Garner's (n.d.) research into fox hunting in Britain, he found that activists expected him to have an opinion on the issue, and this led him to believe that neutrality is not a position that activists can either understand or accept. I also encountered this difficulty, in that activists on both sides of the debate would attempt to solicit and scrutinise my personal beliefs in order to penetrate what they assumed to be my guise of neutrality. Indeed, postmodern and feminist epistemological debates have centred on this very notion of whether pure objectivity when conducting research is either a worthwhile or an achievable aim, given the inescapable influence of researchers' values and personal beliefs on the data collected and analysis supplied. However, by being as selfreflective and as dispassionate as possible, along with reminding participants of my genuine agnosticism on the issue, I made attempts to minimise the "untrammelled incursion of values" (Bryman 2008: 25) into the research process. Had I assumed a position on the issue, it would not only have been dishonest, but would also have resulted in activists assuming certain knowledge and understanding on my part and key explanations of their beliefs and activities may well have been lost.

\section{Studying Dying in Old Age}

Since Gorer's seminal (1965) text describing a post-war Britain as lacking the ritual support necessary for people to make sense of death, there has been consistent academic interest in what has come to be known as the death taboo thesis. Trends towards secularisation and the confinement of death to medical institutions where it is dealt with by paid specialists meant that for proponents of the taboo thesis, death and dying have become sequestered, cut off from the rest of social life, and avoided and feared in equal measure (Elias 1985; Gorer 1965; Illich 1976). For Aries (1983), the French social historian, the "tame" death of the Middle Ages turned into the "wild" death of the $20^{\text {th }}$ Century.

The "revivalism" of the modern hospice movement, with its strong Christian roots, was intended to stand in opposition to the trend towards 
the over-medicalisation and the social sequestration of death and dying (Walter 1994). Hospices were to act as spaces where death could be openly acknowledged and discussed. Revivalism precipitated a new emotional openness around death, with people being informed of their prognosis and encouraged to accept that they were, in fact, dying (acceptance being the fifth stage of Kubler-Ross's (1970) popular five-stage psychological model). As Walter notes (1994: 185), revivalism was supposed to take individualism to its logical conclusion by enabling an individual to claim authority over the medical technologies which tended to alienate him or her from his or her own death, and reflexively to plan for death as the summation of the project of self-identity (Giddens 1991). However, the advancement of individualism in the $20^{\text {th }}$ Century also contributed to the revival of calls for a right to a medically hastened death as one way of keeping the narrative of self-identity intact up until death (Seale 1998: 183). The euthanasia or, as it has latterly become known, the right-to-die movement, entailed a different critique of modernist medicine, one which supported an individual's subjective determinations about the value of his or her own life and his or her desire for its end to be hastened if he or she was "suffering unbearably". ${ }^{1}$

Both the death taboo and the revivalism theses have been the subject of much academic debate since the 1960s and indeed still feature in the writings of those continuing to contribute to the death and dying literature (Davies 2005; Green 2008; Holloway 2007; Howarth 2007; Kellehear 2007; Seale 1998). However, as these and other authors note, there is a paucity of sociological or anthropological literature on dying in old age, particularly within the gerontological field (Clark \& Seymour 1999: 24; Field 2000: 27; Seymour et al. 2005; Sidell 1993: 154). Seymour and colleagues (2005: ix) observe that this topic appears to have been left to the pursuit of specialist palliative care organisations, which have a wider remit than older adults. It is only recently that research on dying in old age has started to be collated, for example by Gott and Ingleton (2011) in their edited collection.

\footnotetext{
${ }^{1}$ This phrase is taken from the most recent attempt to legalise a form of medical assistance to die in England and Wales, the 2006 House of Lords Assisted Dying for the Terminally Ill Bill. This Bill took the term "suffering unbearably" from the Dutch Euthanasia Act, passed in 2002.
} 
International Journal of Ageing and Later Life

The lack of social scientific literature may be due to a desire to break the naturalised association between old age and death, an association that regards death in old age as "timely" or "natural". There has also been a rejection of disengagement theory - the theory that older people slowly withdraw from society in preparation for death (Cummings \& Henry 1961) - on the grounds that it is deemed to contribute to the devaluation or ghettoisation of older people as expectations of disengagement turned into expectations (and even compulsion) to withdraw from social life (Sidell 1993: 157). As a consequence, researchers have learnt to deemphasise disengagement and emphasise diversity (Howarth 1998; Lloyd 2004; Williams 1990).

Howarth (1998: 676), for example, is determined to embrace a "more positive approach to ageing" by reporting that among her interviewees aged $75+$ years, most remained firmly "attached" to life and spent little time contemplating their own death. Given increased longevity, people may no longer think of death as imminent at 65, 75 or even 85 years of age. Yet while she tries to make this argument, Howarth also concedes that some interviewees did speak about their readiness for a welcome death and some even spoke of euthanasia as a legitimate end to protracted suffering. It is evident that fears of being criticised for accepting or accentuating the link between old age and death, given the recent "positive" ageing discourse, have closed down discussions about dying in old age and resulted in a general reluctance to explore the topic at all. Holloway (2007: 123) makes the same point, stating that while repeated psychological studies have shown that, in general, people are more likely to think about and prepare for their own death the older they get, this is played down in current studies concerned with emphasising quality of life in old age. It is the aim of this article to open up debate about attitudes towards death in old age through an exploration of ways in which a group of active (i.e. in no way "disengaged") older people anticipate dying.

In addition to the relative paucity of literature on death and dying in old age, little has been written in the academic sphere about death activism in the UK, and the people who are trying to confront the taboo on death through sustained lobbying of both politicians and the media. Death activism tends to coalesce around what is popularly known as the right-todie movement. McInerney (2000) argues that this can be categorised as a 
"new social movement" arising from a sense of injustice and dissatisfaction with the current "system of dying". Briefly, advocates of a right-to-die propose some form of legalised medical assistance to die given a "considered and persistent" request from an individual. ${ }^{2}$ Those activists who situate themselves on the other side of the debate refuse to accept that there is either a legal or moral right to be granted medical assistance to die. For some of these activists, the objective to increasee the provision and remit of palliative and hospice care should not be jeopardised by focusing on the demands of a small minority. Access to specialist palliative care, they argue, would likely alleviate the vast majority of patients' requests to be helped to die. However, most who oppose legalisation assume a principled opposition, questioning the morality of one person, whether a doctor or otherwise, knowingly causing or hastening the death of another. The effect of the rhetoric and the media coverage given to both sets of activists in this contentious and emotionally charged debate is that of fostering a new, public discourse around the "good death", which presents a different type of challenge to the taboo on death from that offered by hospice revivalism.

\section{The Founding of FATE: Tactics and Motivations}

In November 1999, after disagreements over finances and irreconcilable personality clashes, a few members of EXIT, the Scottish branch of the national Voluntary Euthanasia Society, split off to form a new group, which they called FATE. FATE's founding members determined from the start that they wanted more than a nominal association. They had been dissatisfied with EXIT's lapse into inactivity and they wanted regular meetings and public debates. They were committed to finding a way to share their concerns about their dying. The organisation has three meetings a year and produces a newsletter four times a year. Included in the newsletter are: national and international right-to-die news; the latest book reviews; and articles on new end-of-life research. Since 2002, the group has also been the UK's calling point for people travelling to the

${ }^{2}$ The wording "considered and persistent" is that used in the 2006 House of Lords Assisted Dying for the Terminally Ill Bill. 
International Journal of Ageing and Later Life

Dignitas organisation in Switzerland. Dignitas is a not-for-profit organisation based in Zurich, which helps foreign nationals lawfully to obtain a lethal prescription. FATE produces a guide, distributed only to members, which details all the documentation and procedural requirements necessary for applying to die at Dignitas. The Swiss authorities require a lot of identification, including marriage certificates or "celibacy" certificates (an Affidavit sworn in front of a public notary that you have never been married) and birth certificates of spouses. People can encounter all sorts of problems sourcing this documentation, so FATE offers advice by phone. On average, the group receives 5-6 calls per week routed through one activist's home telephone (there is a rota set up to answer it). The group also lobbies the Scottish Parliament, responding to various public consultations and making links with Members of the Scottish Parliament, specifically Jeremy Purvis and Margot MacDonald, who both tabled parliamentary bills to legalise a form of assisted dying, in 2007 and 2010, respectively.

FATE also has a strong presence at international right-to-die conferences. Its members strongly support the activities of the World \& European Federations of Right-to-Die Societies and value being part of an international movement where they can network closely with other activists. At the 2008 World Federation conference, six FATE delegates attended, whereas there were only three Dignity in Dying representatives present. This shows the importance of such networking opportunities for a small organisation like FATE. FATE had approximately 400 members in 2008. According to Judd's survey in the same year, of the $41 \%$ of members who responded, the average age of members was 68 years. Eighty four per cent belonged to social class one, as defined by the National Statistics Socioeconomic Classification scheme (Judd \& Seale 2011). There are also more women than men involved in the group, which may be a factor of women's longevity - what Arber and Ginn labelled "the feminisation of later life" (1991). The composition of FATE, therefore, is similar to that of the Hemlock Society in the US before it disbanded in 2003. The findings of a survey conducted of the latter (Wilson et al. 1998) indicated that it is predominantly older, white, wealthy, highly educated, economically and politically active women who are at the forefront of the right to die movement in the US. 
FATE activists are concerned with how older people might experience a "good death". Cross-culturally, the good death is usually considered to be one that can be foreseen, prepared for and controlled, and where the dying person is not alone (Bloch \& Parry 1982: 15; Seale \& Van der Geest 2004: 884). The desire for control is certainly an important motivator of right-to-die claims. As one FATE board member told me: "control is my big want". Yet, it is important to note that it is not the only motivating factor. Members reported that they wanted to be able to say when they no longer found any value in their life due to "suffering unbearably" as a result of illness, disease or, in some cases, the co-morbidities accompanying old age. In fact, "slow dying" seemed to be particularly feared as a result of the reduction in quality of life that was anticipated to accompany it. As one activist told me in an interview:

At the end of life, you are going to die anyway so why do you have to go through a lot of pain to finally die? The end is the same - you die.

Frogatt (2001) emphasises that it is the process of general deterioration or "slow dying" in old age that is least well understood, yet is significant in nursing homes, for instance. She reported greater uncertainty about the actual timing of death, with many residents lingering for extended periods in what staff designated the "poorly" category. There is great ambiguity and conflict among caregivers over how dying is defined (Sidell \& Komaromy 2003: 51-52). The "when" of death is much less easy to foresee than amongst younger people, and this gives rise to anxiety among some older people who would rather plan for their death and die "on time". It is not fear of death that motivates the FATE activists, but rather fear of a protracted dying period in which the fragmenting of social bonds and loss of sociality would precede biological death, entailing a loss of personhood. This phenomenon was explained by one FATE activist I interviewed in the following terms:

I mean, you're not the person you were, you're a biological but not biographical person.

The concept of "social death" can be traced back to Hertz's (1960[1907]) now classic study of the double burial in Borneo in which he identified 
International Journal of Ageing and Later Life

that in many parts of the world, death is not considered a "matter of an instant" but is rather a long process of separation from the social group. This same concept of "social death" has been used to describe the experience of people residing in institutions (Mulkay 1993; Sudnow 1967) as they approach death - hospitals, hospices, nursing homes, residential care homes - as well as people living with dementia (Sweeting \& Gilhooly 1997). Lawton, for example, notes that staff in the UK hospice where she was conducting her research described some older patients as having "already turned their faces to the wall and given up", implying they had no desire to continue living (2000: 154). This is a form of selfmanaged disengagement in response to a self-perceived social death. It is to be distinguished from "other-perceived" social death whereby other people perceive the older dying individual to be "as good as dead" and then write them off (Kalish 1968: 254), which may be a deep-seated fear for those people who oppose any change in the law prohibiting assisted dying.

For the FATE activists whom I interviewed and spent time with at meetings and public events, their self-identity was dependent on a sense of agency, which they feared would be compromised by deteriorating bodily and mental capacities. To have the option of travelling to Dignitas, or the campaigned-for option of legalised assistance to die in the UK, would be to have an insurance policy against a self-perceived social death or loss of autonomy. In the US state of Oregon, each year the number of prescriptions written for lethal barbiturates under the Death With Dignity Act is more than the number of deaths from making use of those prescriptions. This suggests that, for many, possessing a lethal prescription does not correspond to an immediate intention to use that prescription, but rather offers an "insurance policy".

The most high-profile activists viewed it as their mission to reveal the "truth" about the miseries of the dying process. One activist, formerly a GP, said:

The palliative care [philosophy] 'you live until you die' is bilge. A lot of people do live peacefully until they die. But for a lot of people the last few weeks of their lives are very unpleasant and their symptoms dominate them to the extent that they can't really think clearly about anything else. And it's that part that they want to avoid. 
Overall, FATE members' determination to fight for their own "timely" death is a way of staving off the fears stemming from the multiple "unknowns" of the dying process. As one of the recurring mottos of the right-to-die movement asserts: it is not death that is feared, but the process of dying.

\section{Differences between FATE and Dignity in Dying}

In describing right-to-die societies as a "new" social movement (McInerney 2000: 137), the adjunct "new" might seem misplaced given that historians of the UK movement trace its origin to an essay by Samuel Williams published in 1870 (Kemp 2002: 12). However, the right-todie movement as a whole has only achieved conspicuous momentum in the last four decades, and its profile bears similarities to other "new" social movements, which have emerged since the 1960s - for example, the civil rights movement; the women's movement; the gay rights movements. Activism turned a corner around this time, shifting its focus from equality in the economic-industrial system to equality in terms of individual rights. Older people's involvement in social movements underwent a similar shift, exemplified by the contrast between the Townsend Movement of the 1930s in America, which had the redistributive aim of securing older people better pensions (Holtzman 1963), and the Gray Panther movement of the 1970s, led by Maggie Kuhn (1991), which was based on an identity politics around old age (Gilleard \& Higgs 2009: 282).

According to Snow et al. (2004: 3), social movements arise when people organise into collectivities to give voice to their grievances and concerns about the rights, welfare and well-being of themselves and others by engaging in various types of collective action. Whereas interest groups typically pursue their objectives through institutionalised means, such as lobbying, social movements pursue theirs mainly by non-institutional means such as marches, boycotts, etc. Although FATE members do not organise public demonstrations as such, the nature of their activism certainly puts them outside any institutional support and differentiates them from Dignity in Dying, the much larger, national organisation lobbying for a legal right to a medically hastened death. New social 
International Journal of Ageing and Later Life

movements are also said to arise "in defense of identity" as individuals struggle to "name" themselves (Johnston et al. 1994: 10). The politics of identity demand that the right not to be discriminated against is culturally recognised and legally upheld. Identity is at stake in the right-to-die debate because it is activists' firmly held belief that their personal identity will be compromised if they die a bad death. This is usually an identity based on a strong belief in autonomy (self-rule or self-actualisation) and in what Isaiah Berlin termed "negative freedom" - the right to noninterference from others (2006[1958]). Activists' social identity as older people is also a factor in their mobilisation. Contrary to Gilleard and Higgs's (2009: 279) view that "age has figured little in the new politics of identity", I would argue that it is the vision of "slow dying" in old age and the spectre of social death, whether as a result of institutionalisation or general "disengagement", which results in some older people wanting to found or join right-to-die societies. In other words, the older people who join right-to-die societies do so as a result of both their own personal belief in autonomy and as a result of a political commitment to "face up" to death as an outcome of old age.

Dignity in Dying is the oldest and largest organisation spearheading the campaign for the legalisation of medically hastened death. It was founded in 1935 as the Voluntary Euthanasia Society, but changed its name in 2006 in a deliberate effort to move away from the negative associations of the word "euthanasia". Since 2000 when the organisation came under new leadership, it has undergone a professionalisation and its agenda has become more mainstream. The aim of those in charge was to transform the organisation into a credible, authoritative and professionally run outfit. ${ }^{3}$ In 2001, the organisation supported Dianne Pretty's case, ${ }^{4}$ which was referred first to the House of Lords and then to the European Court of Human Rights where it was eventually rejected. This high-profile case represented a turning point both in terms of the organisation's campaign-

\footnotetext{
${ }^{3}$ Benjamin, A. 2006. Exit Strategy. The Guardian.

${ }^{4}$ Dianne Pretty petitioned the court to allow her husband, Brian, to help her commit suicide with legal immunity. Dianne was living with Motor Neurone Disease and was paralysed from the neck down, making it very difficult to take her own life.
} 
ing strategy and in increasing the public awareness and acceptability of the right-to-die cause. Having gained respectability as a pressure group through association with this case and, more recently, Debbie Purdy's case, ${ }^{5}$ which garnered an equally large volume of media coverage, Dignity in Dying is now repositioning itself as an organisation that champions "choice" at the end of life. Choice is high on successive government agendas, and as the Chief Executive told members at its AGM in 2008: "it is much more difficult to be against choice than it is assisted dying". Indeed, the organisations that oppose any form of legalised assistance to die, once previously labelled "pro-life", are now labelled "anti-choice".

In its desire to win mainstream support and become the bona fide organisation promoting patient choice at the end-of-life, Dignity in Dying does not dispense any advice to its members about the pragmatics of hastening death. It refuses to give advice about either self-deliverance methods ${ }^{6}$ ("rational" suicide) or travelling to Dignitas, which it views as short-term, even irresponsible goals that may jeopardise its hard-won credibility and invite accusations of illegal practice. Indeed, with the change of the leadership in 2000, any board members who favoured more hands-on "exit" methods or were too involved with the work of Dignitas were asked to leave, some of them decamping to FATE. The organisation now campaigns for a very specific form of medically hastened death called "physician-assisted dying", meaning that lethal prescriptions could only be dispensed to people who are "terminally ill", i.e. have only a few months to live. FATE, on the other hand, campaigns for the right to a medically assisted death for all those who request it on the grounds of suffering. Dignity in Dying's new policy, however, does not suit all its

${ }^{5}$ Debbie Purdy, who has Multiple Sclerosis, wanted a "clarification" of the factors that the Director of Public Prosecution (DPP) would take into account when deciding whether or not to prosecute her husband, Omar Puente, in the event of him helping her travel to Switzerland to end her life. This was the highest-profile legal challenge on this issue since the Pretty case in 2002. Debbie Purdy and Omar Puente won their case at the House of Lords in July 2009 as a result of which the DPP produced an offence-specific policy.

${ }^{6}$ Techniques for taking one's own life when a person has made a "rational" decision to do so due to irreversible illness. 
International Journal of Ageing and Later Life

members, as illustrated by the following comment made by a member of the organisation at its 2008 AGM (to a round of applause and "hear hears" from the audience):

'Terminal' is not the salient point here. Surely if a person's disease is not terminal, then [assisting them to die] is even more pressing!

Unlike Dignity in Dying, FATE gives advice about self-deliverance methods and travelling to Dignitas. Members are determined to help people who are suffering and who feel they cannot wait for any possible future Act of Parliament (which might also be very restrictive in its scope). FATE, which is a much smaller organisation than Dignity in Dying, does not aspire to become a great political lobbying force that needs to be above reproach. As of 2008, there were still only approximately 400 members, as compared to Dignity in Dying's 100,000 members and "supporters" (those who do not pay annual subscriptions but have in the past consulted the organisation). Such a small, relatively informal group does not have the same levels of accountability or hierarchies of governance as an organisation like Dignity in Dying. Members do not have to maintain a corporate view. Instead, they are a collection of individuals with different personal views. Notwithstanding its recent high profile in the media due, in the main, to its involvement with the activities of Dignitas, FATE remains a grassroots organisation, which focuses on regular networking and information sharing among members. While FATE members do not resist Dignity in Dying's professionalisation and mainstreaming agenda (and indeed they would be the beneficiaries should this agenda ever successfully secure an Act of Parliament), they would not compromise on the more "traditional" goals of the right-to-die movement: receiving help to die on the grounds of suffering and autonomy rather than on the grounds of having a "terminal" diagnosis.

The different perspectives of FATE and Dignity in Dying are exemplified by their views on Dignitas. The Swiss organisation has attracted vast amounts of publicity and media attention on an international scale, and this has helped to keep the assisted dying debate in the public arena as much as any Dignity in Dying campaign of recent years, or even its highprofile legal cases. Yet, Dignity in Dying does not support Dignitas' activities. Ostensibly, the organisation's reasoning is that helping someone 
travel to Switzerland could be tantamount to "encouraging or assisting a suicide and therefore a criminal offence" ${ }^{7}$ However, there is also a sense in which many advocates simply do not like the idea of Dignitas. One House of Lords peer who lobbies strongly in favour of assisted dying legislation in Britain told me in an interview that it was "seedy" and that only "eccentric" people would go there to die. Another right-to-die campaigner who had worked at Dignity in Dying for many years told me that she thought it was "freaky" and dangerous because it was unregulated. FATE activists, on the other hand, do not view Dignitas only as a last resort for desperate people. Instead, they embrace the lay (non-medicalised) model of assistance to die, which Dignitas represents (there is no medical professional present when the lethal dose is taken). FATE actively supports Dignitas, and members believe there would be a role for the organisation even if assisted dying were to be made legal in the UK. As one activist who eventually travelled to Dignitas for help to die told me: "the very last thing I want is to be in the hands of others. I do not want to be dealt with as a medical object". It is this long-term support for different types or models of assistance to die, dependent on individual preference, which differentiates FATE members from Dignity in Dying's paid workers. These differences undoubtedly cause some friction between the two organisations. As Dignity in Dying's Human Rights Officer told me:

Because FATE assist people more than they should do legally then we can't have anything to do with them, even if we wanted to. And I'm not sure we would want to.

New social movements often fail to demonstrate the same unity that was evident in the "old" social movements, specifically the working-class and party political movements, which were more hierarchical and centralised (Johnston et al. 1994: 9). While Dignity in Dying has a clear "party line" to uphold, FATE, as one activist told me, prides itself on being a "broad church" of ideas with no need for censorship in the expression of those ideas.

${ }^{7}$ According to Section 2 of the Suicide Act 1961, the wording of which was amended by the Coroners and Justice Act 2009, it is a criminal offence, punishable by up to 14 years in prison, to do an act capable of encouraging or assisting the suicide or attempted suicide of another person. 
International Journal of Ageing and Later Life

\section{Pragmatism and the Pursuit of Freedom}

It is submitted here that FATE's demographic contributes to its nonconformist approach. While it was observed that the majority of members attending Dignity in Dying's 2007 and 2008 AGMs were older than 65, the organisation's paid staff and Chief Executive represent a much younger demographic (they are in their twenties and thirties). As I stated earlier, FATE's membership has an average age of 68 years and 74\% of members are older than 60 (Judd \& Seale 2011). The group's key organisers are mostly retired and therefore have fewer concerns about airing "controversial" views that may impact negatively on their careers (especially for people working in the healthcare professions). The fact that they are not getting paid to be active in the movement suggests a different type of commitment, one not associated with careerism. By the age of 68 years, most people will have experienced the death or physical decline of family and friends and will have begun to contemplate their own. As Brogden (2001: 48) notes, suicide rates are higher amongst older people than any other age group, and the suicide attempts of the old have greater lethality, being made with no warning or requests for help. While there is little agreement about the reasons why older people remain at the highest risk of completed suicides (Kellehear 2007: 229), it is possible to deduce that older people are more determined to assert their will.

Some key members of FATE are also less concerned about skirting the fringes or even personally testing the limits of the law on this issue. For example, one member (and key research participant) was arrested and questioned by police for allegedly giving advice on the phone about the techniques of self-deliverance to a caller who subsequently took his own life. That member is 83 years old. It is a very hands-on form of activism, which is a manifestation of deeply held convictions. Gray Panthers founder Maggie Kuhn summarises the commitment of older activists as follows:

The old, having the benefit of life experience, the time to get things done, and the least to lose by sticking their necks out, [are] in a perfect position to serve as advocates for the larger public good (1991: 38). 
Older people and death activism

The "public good" in which right-to-die activists believe is that of allowing people to die when they want to rather than expending public resources keeping them alive against their will.

My long-term research with FATE led me to conclude that the form that members' activism takes is influenced by their age, in that first and foremost it is guided by pragmatic considerations. Some older members of FATE feel that while they support all political campaigns to change the law on assisted dying, they may not personally have time to wait, if indeed waiting will bring the desired legislative change. This draws them towards matter-of-fact debates about the mechanics of dying and of hastening death, which many outsiders would shrink at. It is not that the moral rightness of their cause is of no interest to activists. Rather, it is that it appears self-evident to them, and therefore the debate, for them at least, can more usefully shift to pragmatics.

FATE's pragmatic mission can be related to Richard Rorty's (1998) pragmatist philosophy. Rather than arguing one's case for a certain course of action from the basis of first principles or from assertions about transcendent human attributes, Rorty (1998: 167) argues that it is better to pose the question "what can we do with ourselves"? He proposes engaging people in effective action which in a simple way makes people's lives better: "niceness champions obedience to moral law" (1998: 182). FATE members' activism reflects this philosophical position. Activists discuss "difficult" cases: deaths that went wrong through bad planning; examples of poor care or poor medical advice; people whose families are proving obstructive. There is little discussion of foundational principles. There is an "ought" that goes without saying, which is that autonomy ought to be respected and suffering relieved. It is tacitly assumed that anybody who attends FATE meetings or phones up to ask advice also takes these two principles as given. And from that perceived indisputable point of departure, pragmatics take centre stage.

Activists are interested in seizing the tools and information they have at their disposal to help people achieve the death that they desire. The group has managed to retain an ethic of freedom of both action and expression that Dignity in Dying appears to have lost in its desire to gain mainstream 
International Journal of Ageing and Later Life

acceptance and to operate very strictly within the law. Whereas Dignity in Dying wants to institutionalise (through legislation) the freedom to die at a time of a person's choosing, the FATE members I got to know are open to adapting to freedom's more contingent character. They want a change in the law, yes, but this would not remove the desire to keep other avenues open - Dignitas, for example - or learning the techniques of selfdeliverance. To be free is to be free to adapt to circumstances and the means available. Relying on the state may not always be an option. Their focus on pragmatics rather than procedures, organisational accountability and, for that matter, legality enables them to enlist freedom's contingency. The political philosopher Foucault wrote about the paradox of trying to legislate for freedom:

Liberty is a practice ... The liberty of man is never assured by the institutions and laws that are intended to guarantee them. This is why almost all of these laws and institutions are quite capable of being turned around. Not because they are ambiguous, but simply because "liberty" is what must be exercised (Foucault 1984: 245).

Part of the desire to resist institutionalising freedom of choice may stem from the fact that many members' motivation for joining the group comes from a determination to resist the societal trend towards institutionalising older people when they become frail due to a shortage of informal care in families (Seale 2005: 381). It is also predominantly older women who live ${ }^{8}$ (and $\mathrm{die}^{9}$ ) in care homes, a fact that, along with greater longevity, perhaps explains why right-to-die societies are also dominated by women. For

${ }^{8}$ According to a 2004 Focus on Gender report published by the UK Office for National Statistics, there were two and half times as many women in residential care and nursing homes compared with men: 269,000 women and 104,000 men. See http:/ / www.unece.org/fileadmin/DAM/stats/gender/publications/UK/ Focus_on_Gender.pdf.

${ }^{9}$ A 2010 National End of Life Intelligence Network Report based on figures from the Office for National Statistics states that a lower proportion of males than females aged 75 and older died in nursing homes (males $9.0 \%$; females $14.2 \%$ ) and old people's homes (6.1\% males; $12.8 \%$ females), and that the proportion of deaths in nursing homes and old people's homes increased with increasing age (p. 7). See www.endoflifecare-intelligence.org.uk/view.aspx?rid $=82$ 
Older people and death activism

many of the members of FATE whom I interviewed and interacted with, it is the prospect of the loss of personal freedom upon moving to an institution, which motivates them to want to become involved in the rightto-die movement. As one activist said:

I would never allow myself to go into a home. I'd have to eat everything they ate. And it would be so incredibly boring. Can you imagine? I've seen far too many homes.

Unwanted institutionalisation and dependency has also been postulated by Kellehear (2009) as a reason why older people might choose to die alone. Although "natural" death is often deemed to be the preserve of the old, FATE's older members would rather die an "unnatural" death than be institutionalised, or forced, as they see it, to suffer the "slow dying" resulting from longevity. Whether they are conforming to a stigmatised view of old age (by fearing dependency) or defying it (by choosing death in order to resist the infirmities of old age or institutionalisation), the societal stigma around old age undoubtedly shapes their anticipation of death.

\section{Conclusion}

Walter et al. (1995) argued that it is the media that brings death out of private homes and hospital wards and makes death present in public life. Yet, I argue here that it is also the passion and convictions of older right-todie campaigners that have helped to stimulate a public debate about death in the UK in recent years and present a particular challenge to the taboo on death. FATE's courting of the media through openly publicising the help it has given to people wanting to travel to Dignitas has resulted in many column inches being devoted to the group, quite disproportionate to the size of its membership. The FATE activists who participated in my research were predominantly retired professionals who want a platform from which to articulate their concerns and demands. They want to facilitate people's "good death" experiences, including their own, and are prepared to engage with the practicalities of suicide in order to do this. While it goes without saying that most older people are not affluent, highly-educated activists and, indeed, that many older people may not desire to maintain their autonomy at all costs (as research by Gott et al. (2008) and Kelner 
International Journal of Ageing and Later Life

(1995) highlights), it is equally important to record and discuss the experiences of older people who refuse paternalism in all its guises (Kellehear 2009). FATE activists' vision of the "good death" is one that is both foreseen and controlled, and where biological and social death converge. The group's main activity is dispensing advice about travelling to Dignitas and, in lieu of this option, methods of self-deliverance. FATE members are more interested in tactics and action now, the moral rightness of their cause appearing self-evident to them. The older age of the FATE activists, and the sense they have of their own impending mortality, means that they have less inclination to cogitate and wait for test cases to come to court or a promised groundswell of public opinion, which may or may not deliver a change in the law. It is these factors that differentiate FATE's modus operandi from that of Dignity in Dying and give its members a very specific orientation to freedom in their approach to death.

\section{Acknowledgements}

I would like to thank all the participants who contributed to this research. The project was funded by the Economic and Social Research Council (Grant number PTA-031-2005-00228).

\section{Corresponding Author}

Naomi Richards, Department of Sociological Studies, University of Sheffield, Elmfield, Northumberland Road, Sheffield, S10 2TU, UK. Email: n.m.richards@sheffield.ac.uk

\section{References}

Arber, S. \& Ginn, J. (1991). Gender and Later Life: A Sociological Analysis of Resources and Constraints. London: Sage.

Aries, P. (1983). Hour of Our Death. Harmondsworth: Penguin.

Barnes, M. (2005). The same old process? Older people, participation and deliberation. Ageing \& Society 25: 245-259.

Berlin, I. (2006[1958]). Two concepts of liberty. In R. E. Goodin \& P. Pettit (eds.), Contemporary Political Philosophy: An Anthology (2nd ed., pp. 369-387). Oxford: Blackwell Publishing. 
Bloch, M. \& Parry, J. (1982). Introduction. In M. Bloch \& J. Parry (eds.), Death and the Regeneration of Life (pp. 1-44). Cambridge: Cambridge University Press.

Brewer, J. D. (2000). Ethnography. Buckingham: Open University Press.

Brogden, M. (2001). Geronticide: Killing the Elderly. London: Jessica Kingsley.

Bryman, A. (2001). Introduction: A review of ethnography. In A. Bryman (ed.), Ethnography: Volume I (pp. ix-xxxix). London: Sage.

Burr, J. A., Caro, F. G. \& Moorhead, J. (2002). Productive aging and civic participation. Journal of Aging Studies 16(1): 87-105.

Choi, L. H. (2003). Factors affecting volunteerism among older adults. Journal of Applied Gerontology 22: 179-196.

Clark, D. \& Seymour, J. (1999). Reflections on Palliative Care. Buckingham/ Philadelphia: Open University Press.

Cummings, E. \& Henry, W. E. (1961). Growing Old: The Process of Disengagement. New York: Basic Books.

Davies, D. J. (2005). A Brief History of Death. Oxford: Blackwell.

Elias, N. (1985). The Loneliness of Dying. Oxford: Basil Blackwell.

Field, D. (2000). Older people's attitudes towards death in England. Mortality 5(3): 277-297.

Foucault, M. (1984). Space, knowledge, and power. In P. Rabinow (ed.), The Foucault Reader (pp. 239-256). London: Penguin Books.

Frogatt, K. (2001). Life and death in English nursing homes: Sequestration or transition? Ageing and Society 21: 319-232.

Garner, A. (n.d). Ethical dilemmas in professional practice in anthropology. Case study 1:"'”'What you shouldn't ask': Environment, landscape and vested interests in England. Association of Social Anthropologists of the UK and Commonwealth. Available on http://www.theasa.org/networks/ apply/ethics/case.shtml (Accessed: October 12, 2011).

Giddens, A. (1991). Modernity and Self-Identity: Self and Society in the Late Modern Age. Cambridge: Polity Press in association with Blackwell.

Gilleard, C. \& Higgs, P. (2000). Cultures of Ageing: Self, Citizen and the Body. Harlow: Pearson Education Limited.

Gilleard, C. \& Higgs, P. (2009). The power of silver: Age and identity politics in the $21^{\text {st }}$ Century. Journal of Aging \& Social Policy 21: 277-295. 
International Journal of Ageing and Later Life

Gorer, G. (1965). Death, Grief, and Mourning in Contemporary Britain. London: Cresset Press.

Gott, M., Small, N., Barnes, S., Payne, S. \& Seamark, D. (2008). Older people's views of a good death in heart failure: Implications for palliative care provision. Social Science \& Medicine 67: 1113-1121.

Gott, M. \& Ingleton, C. (eds.) (2011). Living with Ageing and Dying: International Perspectives on End of Life Care for Older People. Oxford: Oxford University Press.

Green, J. (2008). Beyond the Good Death: the Anthropology of Modern Dying. Philadelphia: University of Pennsylvania Press.

Hertz, R. (1960[1907]). Death and the Right Hand. Aberdeen: Cohen \& West.

Holloway, M. (2007). Negotiating Death in Contemporary Health and Social care. Bristol: The Policy Press.

Holtzman, A. (1963). The Townsend Movement: A Political Study. New York, NY: Basic Books.

Howarth, G. (1998). 'Just live for today'. Living, caring, ageing and dying. Ageing and Society 18: 673-689.

Howarth, G. (2007). Death \& Dying: A Sociological Introduction. Cambridge: Polity Press.

Illich, I. (1976). Limits to Medicine: Medical Nemesis; the Expropriation of Health. Harmondsworth: Penguin.

Jean-Klein, I. \& Riles, A. (2005). Introducing discipline: Anthropology and human rights administrations. Political and Legal Anthropology Review 28: 137-202.

Johnston, H., Larana, E. \& Gusfield, J. (1994). Identities, grievances and new social movements. In E. Larana, H. Johnston \& J. Gusfield (eds.), New Social Movements: From Ideology to Identity (pp. 3-35). Philadelphia, PA: Temple University Press.

Judd, M. \& Seale, C. (2011). Joining a right-to-die society: Motivation, beliefs, and experiences'. Mortality 16(3): 223-241.

Kalish, R. A. (1968). Life and death - Dividing the invisible. Social Science and Medicine 2: 249-259.

Katz, J. (2001[1983]). A theory of qualitative methodology: The social system of analytic fieldwork. In A. Bryman (ed.), Ethnography: Volume IV (pp. 197-120). London: Sage. 
Kellehear, A. (2007). A Social History of Dying. Cambridge: Cambridge University Press.

Kellehear, A. (2009). Dying old - and preferably alone? Agency, resistance and dissent at the end of life. International Journal of Ageing and Later Life 4(1): 5-21.

Kelner, M. (1995). Activists and delegators: Elderly patients' preferences about control at the end of life. Social Science \& Medicine 41: 537-545.

Kemp, N. (2002). Merciful Release: The History of the British Euthanasia Movement. Manchester: Manchester University Press.

Kübler-Ross, E. (1970). On Death and Dying. London: Tavistock Publications.

Kuhn, M. (1991). No Stone Unturned. New York, NY: Ballantine Books.

Lawton, J. (2000). The Dying Process: Patients' Experiences of Palliative Care. London: Routledge.

Lloyd, L. (2004). Mortality and morality: Ageing and the ethics of care. Ageing \& Society 24: 235-256.

Macdonald, B. with Rich, C. (1985). Look Me in the Eye: Old Women, Aging and Ageism. London: The Women's Press.

Martinson, M. \& Minkler, M. (2006). Civic engagement and older adults: A critical perspective. The Gerontologist 46(3): 318-324.

McInerney, F. (2000). "Requested death": A new social movement. Social Science \& Medicine 50: 137-154.

Morrow-Howell, N. (2000). Productive Engagement of Older Adults: Effects on Well-being. Washington University, MO: Center for Social Development.

Mulkay, M. (1993). Social death in Britain. In D. Clark (ed.), The Sociology of Death: Theory, Culture, Practice (pp. 31-50). Oxford: Blackwell/The Sociological Review.

Patton, M. Q. (2001[1990]). Purposeful sampling. In A. Bryman (ed.), Ethnography: Volume II (pp. 106-122). London: Sage.

Rorty, R. (1998). Truth and Progress: Philosophical Papers. Cambridge: Cambridge University Press.

Scott-Jones, J. \& Watt, S. (2010). Ethnography in Social Science Practice. London: Routledge.

Seale, C. (1998). Constructing Death: The Sociology of Dying and Bereavement. Cambridge: Cambridge University Press. 
International Journal of Ageing and Later Life

Seale, C. \& van der Geest, S. (2004). Good and bad death: an introduction. Social Science \& Medicine 58(5): 883-885.

Seale, C. (2005). The transformation of dying in old societies. In M. Johnson (ed.), The Cambridge Handbook of Age and Ageing (pp. 378-386). Cambridge: Cambridge: University Press.

Seymour, J., Witherspoon, R., Gott, M., Ross, H., Payne, S. \& Owen, T. (2005). End-of-Life Care: Promoting Comfort, Choice, and Well-Being for Older People. Bristol: Policy Press (in association with Help the Aged).

Sidell, M. (1993). Death, dying and bereavement. In J. Bond, P. Coleman \& S. Pearce (eds.), Ageing in Society: An Introduction to Social Gerontology (pp. 151-179). Buckingham: Open University.

Sidell, M. \& Komaromy, C. (2003). Who dies in care homes for older people? In J. S. Katz \& S. Peace. (eds.), End-of-Life Care Homes: A Palliative Approach (pp. 43-57). Oxford: Oxford University Press.

Snow, D. A., Soule, S. A. \& Kriesi, H. (2004). Mapping the Terrain. In D. A. Snow, S. A. Soule \& H. Kriesi (eds.), The Blackwell Companion to Social Movements (pp. 3-16). Oxford: Blackwell Publishing.

Sudnow, D. (1967). Passing On: The Social Organisation of Dying. Englewood Cliffs, NJ: Prentice Hall Inc.

Sweeting, H. \& Gilhooly, M. (1997). Dementia and the phenomenon of social death. Sociology of Health \& Illness 19(1): 93-117.

Walter, T. (1994). The Revival of Death. London: Routledge.

Walter, T., Pickering, M. \& Littlewood, J. (1995). Death in the news: The public invigilation of private emotion. Sociology 29: 579-596.

Warburton, J. \& McLaughlin, D. (2005). 'Lots of little kindnesses': Valuing the role of older Australians as informal volunteers in the community. Ageing \& Society 25(5): 715-730.

Williams, R. (1990). The Protestant Legacy: Attitudes to Death and Illness Among Older Aberdonians. Oxford: Clarendon Press.

Wilson, J. K., Fox, E. \& Kamakahi, J. J. (1998). Who is fighting for the right to die? Older women's participation in the Hemlock Society. Health Care for Women International 19(5): 365-380. 